\title{
PENENTUAN HARGA JUAL KAMAR MELALUI IMPLEMENTASI ACTIVITY BASED COSTING SYSTEM PADA PT TASIK RIA RESORT MANADO
}

\author{
Thalia Claudia Tumanduk ${ }^{1}$, Ventje Ilat ${ }^{2}$, Hendrik Gamaliel $^{3}$ \\ ${ }^{1,2,3}$ Jurusan Akuntansi, Fakultas Ekonomi dan Bisnis, Universitas Sam Ratulangi, Jl. Kampus Bahu, Manado, \\ 95115, Indonesia
}

E-mail : tumandukthalia@gmail.com

\begin{abstract}
Development services company primarily in the field of tourism and hospitality, led to increasing competition among hotels. Because it takes strategy to excel in competing, by minimizing and calculate the cost of production effectively so that the selling price is low. The lower the selling price of the product into a high sales rate. Method of activity based costing ( $\mathrm{ABC})$ is very effective in determining the slling price, because $\mathrm{ABC}$ is a method of charging is to charge and collect a fee based activities based on the behavior of existing activities. This study aims to: (1) obtain the calculation result by using ABC method in determining the selling price of room at PT Tasik Ria Resort Manado (2) to compare the selling price of room at PT Tasik Ria Resort Manado using traditional accounting method and $\mathrm{ABC}$. The method of analysis used in this research is descriptive method of comparative and the type of research used is descriptive qualitative. The results obtained that there is a difference between the selling price of PT Tasik Ria Resort Manado and $\mathrm{ABC}$ selling price, where the calculation of $\mathrm{ABC}$ in the rom types Pool View, Sea View and Grand Sea View rooms gives a smaller result than the selling price set by the management. While in the room type Garden View ABC calculation is higher than the sale price of rooms that have been set by the hotel management.
\end{abstract}

Keywords: Activity Based Costing, Activity, Selling Price of Room.

\section{PENDAHULUAN}

Industri pariwisata yang saat ini sedang berkembang pesat di Indonesia yaitu industri perhotelan. Adanya pertambahan jumlah hotel dari tahun ke tahun menunjukkan lingkungan bisnis perhotelan semakin kompetitif. Iklim kompetitif mengharuskan perusahaan untuk mampu bersaing. Untuk dapat bersaing, manajemen perusahaan harus mampu mengelola secara efektif dan efisien seluruh potensi yang ada pada perusahaan. Salah satu strategi yang digunakan untuk mencapai keunggulan bersaing yaitu dengan meminimalkan dan menghitung biaya produksi secara efektif agar harga jual rendah. Dengan harga jual yang semakin rendah, maka tingkat penjualan produk menjadi tinggi. Hal ini dikarenakan dalam pasar bebas konsumen cenderung untuk memilih produk yang murah. Maka dari itu, perusahaan harus benar-benar teliti dalam menghitung dan membebankan biaya sehingga dapat menghasilkan harga pokok produksi yang tepat.

Harga pokok memiliki peranan yang sangat penting dalam penentuan harga jual produk/jasa. Oleh karena itu, peruhasaan harus benar-benar teliti menangani harga pokok produksinya. Menghitung harga pokok produk masih banyak hotel yang menggunakan sistem akuntansi biaya tradisional, seperti full costing dan variabel costing yang menggunakan volume produksi sebagai dasar untuk mengalokasikan biaya produksinya. Sistem tersebut tidak sesuai dengan lingkungan pemanufakturan yang maju, pada diversifikasi (keanekaragaman) produk yang tinggi. Biaya produk yang dihasilkan oleh sistem akuntansi biaya tradisional memberikan informasi biaya yang terdistorsi. Terjadinya distorsi karena 
ketidakakuratan dalam pembebanan biaya, akibatnya adanya kesalahan penentuan biaya, perencanaan, pengendalian dan pembuatan keputusan. Oleh karena itu, maka dikembangkan metode Activity Based Costing System (ABC) untuk mengatasi distorsi pada akuntansi biaya tradisional.

Metode ABC sangat efektif digunakan dalam penentuan tarif inap, dikarenakan ABC merupakan sebuah metode pembebanan biaya yang membebankan biaya berdasarkan aktivitas yang dikerjakan dalam suatu organisasi dan mengumpulkan biaya berdasarkan perilaku yang ada dari aktivitas yang dilakukan untuk menentukan harga jasa layanan inap. Metode ABC mengalokasikan biaya berdasarkan aktivitas sehingga diharapkan dapat memberikan pengukuran yang lebih akurat atas biaya-biaya pemicu aktivitas, yang membantu manajer memperbaiki produk atau jasa dan proses menilai dengan membuat keputusan yang lebih baik. Sistem ABC dapat menyediakan informasi perhitungan biaya yang lebih akurat dan dapat membantu manajemen mengelola perusahaan secara efisien serta memperoleh pemahaman yang lebih baik atas keunggulan kompetitif, kekuatan, dan kelemahan perusahaan. Sehingga dengan metode ABC dapat menyajikan secara cermat dan akurat mengenai informasi harga pokok produk/jasa bagi kepentingan manajemen perusahaan.

PT Tasik Ria Resort Manado merupakan salah satu penyedia jasa di bidang perhotelan. Dari karakteristik spesifikasi jenis penginapan, services, serta potensi persaingan dari competitor maka metode $\mathrm{ABC}$ merupakan salah satu alternatif solusi yang ditempuh oleh perusahaan dalam upaya meningkatkan efisiensi biayanya dan menghitung harga pokok produksi/jasa sebagai acuan untuk menentukan harga jual kamar karena dapat mengukur secara cermat biaya-biaya yang keluar dari setiap aktivitas. Hal ini disebabkan karena dalam pembebanan biaya overhead banyak cost driver (pemicu biaya) yang digunakan, sehingga dalam metode $\mathrm{ABC}$ dapat meningkatkan ketelitian dalam perincian biaya dan keakuratan dalam pembebanan biaya.

\section{TINJAUAN PUSTAKA}

\subsection{Akuntansi Biaya}

Akuntansi biaya adalah suatu proses pencatatan, pengklasifikasian, perhitungan, dan penyajian biaya-biaya pembuatan dan penjualan produk barang maupun jasa dengan cara tertentu sebagai alat pembantu bagi manajemen dalam pengambilan keputusan. Ahmad (2014:4) mengemukakan akuntansi biaya adalah bagian dari akuntansi manajemen dimana merupakan salah satu dari bidang khusus akuntansi yang menekankan pada penentuan dan pengendalian biaya. Sedangkan dalam pengelolaan perusahaan, akuntansi biaya merupakan bagian penting dari ilmu akuntansi dan telah berkembang menjadi tools of management, yang berfungsi menyediakan informasi biaya bagi kepentingan manajemen agar dapat menjalankan fungsinya dengan baik.

\subsection{Biaya}

Ahmad (2014:22) menyatakan bahwa biaya (cost) adalah pengeluaran-pengeluaran atau nilai pengorbanan untuk memperoleh barang atau jasa yang berguna untuk masa yang akan datang, atau mempunyai manfaat melebihi satu periode akuntansi. Biaya memiliki pengertian yang berbeda dengan beban, biaya merupakan pengorbanan sumber ekonomi/penurunan hak kekayaan pemilik berupa kas atau sesuatu yang dapat diukur dalam satuan uang yang diharapkan dapat menghasilkan keuntungan di masa ini dan masa yang akan datang, sedangkan beban adalah biaya/pengorbanan yang manfaatnya sudah dinikmati karena telah habis pakai.

\subsection{Harga Pokok Produksi}

Dunia dan Abdullah (2012:42) menyatakan bahwa biaya yang terjadi sehubungan dengan produksi, yaitu jumlah biaya langsung biaya dan biaya tidak langsung. Siregar dkk 
(2014:28) mengemukakan bahwa harga pokok produksi adalah biaya yang terjadi untuk mengubah bahan baku menjadi barang jadi. Informasi mengenai harga pokok produksi menjadi dasar bagi manajemen dalam pengambilan keputusan untuk menentukan harga jual produk yang bersangkutan.

\subsection{Akuntansi Biaya Tradisional}

Slamet (2016:98) mengemukakan sistem tradisional adalah perhitungan yang hanya membebankan biaya produksi pada produk, biaya produk biasanya dimonitor dari tiga komponen biaya yaitu bahan baku, tenaga kerja langsung dan overhead pabrik. Dalam membebankan biaya overhead pabrik pada produk sistem tradisional hanya menggunakan cost driver aktivitas berlevel unit. Hal tersebut adalah faktor yang menyebabkan perubahan biaya sesuai dengan perubahan unit produk yang diproduksi. Sistem tradisional akan menimbulkan distorsi biaya jika digunakan dalam lingkungan perusahaan manufaktur maju dan dalam persaingan tingkat global. Sistem penentuan harga pokok produksi harus disesuaikan dengan sistem yang cocok dengan lingkungan perusahaannya. Jika sistem penentuan harga pokok produksi tidak dirubah akan menyebabkan distorsi biaya yang besar.

\subsection{Activity Based Costing System (ABC)}

Siregar dkk (2014:240) menyatakan bahwa ABC merupakan metode penentuan biaya produk yang pembebanan biaya overhead berdasarkan pada aktivitas-aktivitas yang dilakukan dalam kaitannya dengan proses produksi. Dengan adanya ABC dapat dihitung harga pokok suatu produk atau jasa yang dapat digunakan oleh manajemen sebagai salah satu alternatif untuk penentuan harga jual. Witjaksono (2013:440) mengemukakan bahwa ABC adalah suatu metode akuntansi biaya dimana pembebanan harga pokok produk merupakan penjumlahan seluruh biaya aktivitas yang menghasilkan (produksi) barang atau jasa. Fokus utama $\mathrm{ABC}$ adalah aktivitas. Mengidentifikasi biaya aktivitas dan kemudian ke produk merupakan langkah dalam menyusun ABC System (Rudianto, 2013:159). ABC mengakui hubungan sebab akibat atau hubungan langsung antara biaya sumber daya, penggerak biaya, aktivitas, dan objek biaya dalam membebankan biaya pada aktivitas dan kemudian pada objek biaya.

\subsection{Cost Driver}

Warindrani (2013:28) menyatakan bahwa pengertian cost driver atau pemicu biaya adalah dasar alokasi yang digunakan dalam ABC System yang merupakan faktor-faktor yang menentukan seberapa besar atau seberapa banyak usaha dan beban kerja yang dibutuhkan untuk melakukan suatu aktivitas. Cost driver digunakan untuk menghitung biaya sumber dari setiap unit aktivitas. Kemudian setiap biaya sumber daya dibebankan ke produk atau jasa dengan mengalihkan biaya setiap aktivitas dengan kuantitas setiap aktivitas yang di konsumsikan.

Cost driver merupakan faktor-faktor yang menyebabkan terjadi biaya dan aktivitas merupakan dampak yang ditimbulkannya, cost driver faktor yang dapat diukur yang digunakan untuk membebankan biaya ke aktivitas dan dari aktivitas satu ke aktivitas lainnya.

\subsection{Perbandingan Biaya Produk Sistem Tradisional dan Sistem ABC}

Dunia dan Wasilah (2012:321) menggambarkan perbedaan antara penerapan ABC dan sistem tradisional, yaitu :

1. Pada cara pengalokasian biaya-biaya tidak langsung kepada objek biaya. Untuk biaya langsung, dapat dilakukan dengan cara pembebanan langsung kepada masing-masing objek biaya karena dapat dilakukan penelusuran secara mudah. Untuk biaya tidak langsung, tidak mungkin dilakukan penelusuran langsung pada objek biaya, karena banyak jenis biaya yang harus dibebankan tetapi tidak ditemukan hubungannya dengan objek biayanya.

2. Pada sistem tradisional seluruh biaya tidak langsung akan dikumpulkan dalam satu pengelompokan biaya (cost pool), kemudian seluruh total biaya tersebut dialokasikan 
dengan satu dasar peengalokasikan biasanya berdasarkan hubungan sebab akibat. Misalnya, jika biaya tidak langsung suatu perusahaan didominasi oleh biaya overhead pabrik yang sangat otomatis prosesnya, maka bisa saja dasar pengalokasian yang dipilih adalah jam kerja mesin.

3. Pada sistem ABC seluruh biaya akan di kelompokkan (cost pool) sesuai dengan aktivitas masing-masing yang berhubungan, kemudian masing-masing kelompok biaya tersebut dihubungkan dengan masing-masing aktivitas tersebut dan dialokasikan berdasarkan aktivitasnya masing-masing. Pemilihan kelompok biaya biasanya berdasarkan aktivitas yang sesuai dengan hierarki biaya dan hampir sama kegiatannya. Sedangkan untuk pemilihan dasar alokasi adalah jumlah aktivitas dalam setiap kelompok biaya tersebut.

\subsection{Jasa Perhotelan}

Hotel Menurut Sulastinoyo (2011:5) yaitu suatu perusahaan yang dikelola oleh pemiliknya dengan menyediakan fasilitas kamar untuk tidur kepada orang-orang yang melakukan perjalanan serta menyediakan pelayanan makan dan minum, dengan membayar sejumlah uang yang wajar sesuai dengan pelayanan yang diterima. Biaya dalam hotel didefinisikan sebagai penggunaan kas atau terjadinya utang atau kombinasi keduanya dalam rangka membeli barang atau jasa untuk kegiatan operasional hotel (Darminto dan Suryo 2012:19). Ada tiga jenis biaya yang ada dalam hotel menurut Darminto dan Suryo (2012:21), yaitu biaya langsung, biaya tidak langsung dan biaya atau beban tetap.

\subsection{Penentuan Harga Jual}

Penentuan harga jual merupakan salah satu keputusan manajemen. Swastha (2013:154) menyatakan bahwa metode penentuan harga jual yang berdasarkan biaya dalam bentuk yang paling sederhana, yaitu :

1. Cost plus pricing method adalah penetapan harga jual dengan menambahkan sejumlah (presentase) tertentu dari harga pokok atau biaya sebagai keuntungannya.

2. Mark up pricing method adalah selisih antara harga jual suatu produk atau jasa dengan harga pokoknya.

3. Penentuan harga oleh produsen adalah awal dari rangkaian harga yang ditetapkan oleh perusahaan-perusahaan lain dalam distribusi.

\subsection{Penelitian Terdahulu}

Ardino tahun 2017 dengan judul Analisis penerapan metode activity based costing dalam menentukan sewa kamar penginapan (studi pada Wakatobi Dive Resort Onemoba'a Tomia). Hasil penelitian menunjukkan Terdapat selisih tarif sewa kamar penginapan yang lebih tinggi pada tipe penginapan Garden Bungalow dan Beach Bungalow dari hasil perhitungan metode Activity Based Costing dengan perhitungan pihak perusahaan dengan pendekatan metode tradisional yaitu masing-masing sebesar Rp. 942.777,43. dan Rp. 221.554,07. Sedangkan tarif sewa kamar penginapan yang lebih rendah dengan menggunakan metode Activity Based Costing, yaitu pada tipe penginapan Villa yaitu sebesar Rp. 462.434,69.

\section{METODE PENELITIAN}

\subsection{Jenis dan sumber data}

Jenis penelitian yang digunakan dalam penelitian ini adalah penelitian deskriptif kualitatif dengan pendekatan studi kasus yaitu menggambarkan atau mendeskripsikan secara sistematis mengenai unit cost yang terkait dengan proses penyediaan jasa penginapan di PT Tasik Ria Resort Manado dengan menggunakan metode Activity Based Costing (ABC).'

\subsection{Tempat dan Waktu Penelitian}

Penelitian ini dilakukan di PT Tasik Ria Resort Manado yang merupakan salah satu perusahaan jasa yang bergerak dalam bidang perhotelan terletak di jalan raya Trans Sulawesi, 
Desa Mokupa, Tombariri, Manado, Sulawesi Utara. Waktu penelitian dilaksanakan pada bulan Maret 2018 sampai dengan selesai.

\subsection{Metode Analisis}

Metode analisis yang digunakan pada penelitian ini adalah metode analisis deskriptif komparatif yang menunjukkan dan membandingkan metode perhitungan harga pokok untuk menentukan harga jual kamar yang diterapkan PT Tasik Ria Resort selama ini dengan menggunakan Activity Based Costing System.

Adapun langkah-langkah yang dilakukan dalam penelitian ini antara lain:

1. Mengidentifikasi aktivitas

Aktivitas-aktivitas PT Tasik Ria Resort merupakan seluruh kegiatan yang terjadi atau dilakukan di resort dalam menyediakan jasa seperti, aktivitas penginapan, aktivitas laundry, aktivitas pemberian makan pagi, aktivitas penyusutan, aktivitas listrik dan air, aktivitas pemeliharaan bangunan dan fasilitas, aktivitas pemasaran, aktivitas penggajian.

2. Mengklasifikasikan biaya berdasar aktivitas ke dalam berbagai level aktivitas.

3. Mengidentifikasi cost driver.

4. Menentukan tarif per unit cost driver

Untuk menentukan tarif per unit dapat dihitung dengan rumus:

Tarif per unit cost driver

$$
=\frac{\text { Jumlah aktivitas }}{\text { cost driver }}
$$

5. Membebankan biaya ke produk dengan menggunakan tarif cost driver dan ukuran aktivitas. Pembebanan biaya overhead dari tiap aktivitas ke setiap penginapan dihitung dengan rumus:

BOP yang dibebankan $=$ Tarif per unit cost driver $\mathrm{x}$ cost driver yang digunakan

6. Kemudian perhitungan harga jual masing-masing tipe kamar dengan metode activity based costing dapat dihitung dengan rumus sebagai berikut:

Harga Jual per kamar = Harga pokok per kamar + laba yang diharapkan

7. Membandingkan harga jual yang ditetapkan PT Tasik Ria Resort Manado dengan harga jual yang ditentukan menggunakan Activity Based Costing.

8. Menarik kesimpulan dari perbandingan harga yang terjadi.

\section{HASIL ANALISIS DAN PEMBAHASAN}

4.1. Hasil Analisis

Dari hasil wawancara dengan Front Office Manager jenis kamar di PT Tasik Ria

Resort, antara lain :

1. Garden View, yang berjumlah 12 kamar dengan luas sebesar $24.5 \mathrm{~m}^{2}$.

2. Pool View, yang berjumlah 20 kamar dengan luas sebesar $36 \mathrm{~m}^{2}$.

3. Sea View, yang berjumlah 11 kamar dengan luas sebesar $48 \mathrm{~m}^{2}$.

4. Grand Sea View, yang berumlah 4 kamar dengan luas sebesar $66 \mathrm{~m}^{2}$.

Tabel 1. Room Rate PT Tasik Ria Resort Tahun 2018

\begin{tabular}{|l|c|}
\hline \multicolumn{1}{|c|}{ Jenis Kamar } & Room Rate/Hari \\
\hline Garden View & Rp.584.000 \\
\hline Pool View & Rp.797.000 \\
\hline Sea View & Rp.1.089.000 \\
\hline Grand Sea View & Rp.1.452.000 \\
\hline
\end{tabular}

Sumber: PT Tasik Ria Resort, 2018. 
Tabel 1. menunjukkan harga jual kamar per hari PT Tasik Ria Resort pada tahun 2018, harga tersebut sudah termasuk pajak yang dikenakan pihak hotel kepada pelanggan.

Tabel 2. Jumlah Kamar Tersedia untuk Dijual

\begin{tabular}{|l|c|c|}
\hline \multicolumn{1}{|c|}{ Jenis Kamar } & $\begin{array}{c}\text { Jumlah Kamar } \\
\text { (1) }\end{array}$ & $\begin{array}{c}\text { Jumlah Kamar Setahun } \\
\text { (1) } \mathbf{x} \text { 365 Hari }\end{array}$ \\
\hline Garden View & 12 & 4.380 \\
\hline Pool View & 20 & 7.300 \\
\hline Sea View & 11 & 4.015 \\
\hline Grand Sea View & 4 & 1.460 \\
\hline Jumlah & $\mathbf{4 7}$ & $\mathbf{1 7 . 1 5 5}$ \\
\hline
\end{tabular}

Sumber: PT Tasik Ria Resort, 2018.

Tabel 2. menunjukkan jumlah kamar tersedia untuk dijual disetiap jenis kamar selama tahun 2017 adalah 17.155, dari hasil perhitungan banyaknya kamar dikali 365 hari.

Tabel 3. Jumlah Hari Hunian Kamar PT Tasik Ria Resort Tahun 2017

\begin{tabular}{|l|c|c|c|c|}
\hline \multicolumn{1}{|c|}{ Bulan } & Garden View & Pool View & Sea View & Grand Sea View \\
\hline Januari & 50 & 197 & 89 & 18 \\
\hline Februari & 118 & 302 & 276 & 22 \\
\hline Maret & 200 & 313 & 313 & 55 \\
\hline April & 166 & 357 & 252 & 53 \\
\hline Mei & 156 & 279 & 275 & 33 \\
\hline Juni & 94 & 239 & 196 & 32 \\
\hline Juli & 60 & 196 & 107 & 24 \\
\hline Agustus & 218 & 330 & 344 & 56 \\
\hline September & 84 & 264 & 206 & 24 \\
\hline Oktober & 104 & 374 & 295 & 63 \\
\hline November & 190 & 285 & 198 & 92 \\
\hline Desember & 212 & 301 & 245 & 46 \\
\hline Jumlah & $\mathbf{1 . 6 5 2}$ & $\mathbf{3 . 4 3 7}$ & $\mathbf{2 . 7 9 6}$ & $\mathbf{5 1 8}$ \\
\hline
\end{tabular}

Sumber: PT Tasik Ria Resort, 2018.

Tabel 3. menunjukkan jumlah hari hunian kamar PT Tasik Ria Resort selama tahun 2017 untuk kamar jenis Garden View sebesar 1.652, kamar jenis Pool View sebesar 3.437, kamar jenis Sea View sebesar 2.796, kamar jenis Grand Sea View sebesar 518.

Tabel 4. Pendapatan Penjualan Jasa Kamar PT Tasik Ria Resort Tahun 2017

\begin{tabular}{|c|c|c|c|}
\hline Jenis Kamar & $\begin{array}{l}\text { Jumlah Kamar } \\
\text { Terjual } \\
\text { (1) }\end{array}$ & $\begin{array}{c}\text { Harga Jual Kamar } \\
\text { (Rp.) } \\
\text { (2) }\end{array}$ & $\begin{array}{c}\text { Pendapatan Jasa } \\
\text { Kamar (Rp.) } \\
\text { (1) } x(2)\end{array}$ \\
\hline Garden View & 1.652 & 584.000 & 964.768 .000 \\
\hline Pool View & 3.437 & 797.000 & 2.739 .289 .000 \\
\hline Sea View & 2.796 & 1.089 .000 & 3.044 .844 .000 \\
\hline Grand Sea View & 518 & 1.452 .000 & 752.136 .000 \\
\hline Jumlah & 8.403 & 3.922 .000 & 7.501 .037 .000 \\
\hline
\end{tabular}

Sumber: PT Tasik Ria Resort, 2018. 
Tabel 4. menunjukkan pendapatan penjualan jasa kamar PT Tasik Ria Resort selama tahun 2017 sebesar Rp.7.501.037.000 dari hasil perhitungan jumlah kamar terjual dikali dengan harga jual kamar.

\section{Perhitungan Harga Pokok Kamar Dengan Metode Activity Based Costing System}

Langkah-langkah yang dilakukan dalam menghitung harga pokok kamar dengan menggunakan metode $\mathrm{ABC}$ :

1. Mengidentifikasi aktivitas dan mengklasifikasi biaya berdasar aktivitas ke dalam berbagai level aktivitas

Tabel 5. Identifikasi Aktivitas dan Klasifikasi Biaya Berdasar Aktivitas

\begin{tabular}{|c|c|c|}
\hline No. & Aktivitas & Level Aktivitas \\
\hline 1. & Penginapan & Unit Level \\
\hline 2. & Laundry & Unit Level \\
\hline 3. & Pemberian Makan Pagi & Unit Level \\
\hline 4. & Pemasaran & Product Level \\
\hline 5. & Listrik & Facility Level \\
\hline 6. & Air & Facility Level \\
\hline 7. & Penggajian & Facility Level \\
\hline 8. & Penyusutan & Facility Level \\
\hline 9. & Pemeliharaan & Facility Level \\
\hline
\end{tabular}

Sumber : Data hasil olahan, 2018.

2. Mengidentifikasi cost driver

Tabel 6. Cost Pool dan Cost Driver

\begin{tabular}{|l|c|}
\hline \multicolumn{1}{|c|}{ Cost Pool } & Cost Driver \\
\hline Unit Level activity: & \\
Pool I & Jumlah kamar terjual \\
Aktivitas penginapan & Jumlah kamar terjual \\
Aktivitas laundry & \\
Pool II & Jumlah tamu menginap \\
Aktivitas pemberian makan pagi & \\
\hline Product-sustaining activity: & \\
Pool III & Jumlah kamar tersedia \\
Aktivitas pemasaran & \\
\hline Facility-sustaining activity: & \\
Pool IV & Jumlah kWh \\
Aktivitas listrik & \\
Pool V & Jumlah $^{3}$ \\
Aktivitas air & \\
Pool VI & \\
Aktivitas penggajian & Jumlah bulan kerja karyawan \\
Pool VII & \\
Aktivitas penyusutan & Jumlah luas lantai \\
Aktivitas pemeliharaan & Jumlah luas lantai \\
\hline
\end{tabular}

Sumber : Data hasil olahan, 2018.

Tabel 6. menjelaskan bahwa Cost Pool I yang dijadikan cost driver adalah jumlah kamar terjual, Cost Pool II yang dijadikan cost driver adalah jumlah tamu menginap, Cost Pool III 
yang dijadikan cost driver adalah jumlah kamar tersedia, Cost Pool IV yang dijadikan cost driver adalah jumlah $\mathrm{kWh}$, Cost Pool V yang dijadikan cost driver adalah jumlah $\mathrm{m}^{3}$, Cost Pool VI yang dijadikan cost driver adalah jumlah bulan kerja karyawan dan Cost Pool VII yang dijadikan cost driver adalah jumlah luas lantai.

3. Membebankan biaya overhead

Tabel 7. Biaya Activity Cost Pool

\begin{tabular}{|c|c|}
\hline Aktivitas & Biaya $(\mathbf{R p .})$ \\
\hline \multicolumn{2}{|l|}{ Cost Pool I } \\
\hline \multicolumn{2}{|l|}{ Aktivitas Penginapan : } \\
\hline Room amenities & 171.001 .050 \\
\hline Cleaning supplies & 67.671 .759 \\
\hline \multicolumn{2}{|l|}{ Aktivitas Laundry . } \\
\hline Laundry linen & 118.361 .400 \\
\hline Jumlah & 357.034.209 \\
\hline \multicolumn{2}{|l|}{ Cost Pool II } \\
\hline \multicolumn{2}{|l|}{$\begin{array}{l}\text { Aktivitas Pemberian Makan Pagi : } \\
\text { Full breakfast buffet (Rp. } 35.000 \times 16.806 \text { orang) }\end{array}$} \\
\hline Full breakfast buffet (Rp.35.000 × 16.806 orang) & 588.210 .000 \\
\hline Jumlah & 588.210 .000 \\
\hline \multicolumn{2}{|l|}{ Cost Pool III } \\
\hline \multicolumn{2}{|l|}{ Aktivitas Pemasaran : } \\
\hline Advertising \& Promotion & 21.150 .000 \\
\hline \multicolumn{2}{|l|}{ Jumlah } \\
\hline \multicolumn{2}{|l|}{ Cost Pool IV } \\
\hline \multicolumn{2}{|l|}{ Aktivitas Listrik: } \\
\hline Listrik & 378.870 .271 \\
\hline Jumlah & 378.870.271 \\
\hline \multicolumn{2}{|l|}{ Cost Pool V } \\
\hline \multicolumn{2}{|l|}{ Aktivitas Air : } \\
\hline Air & 34.155 .000 \\
\hline Jumlah & 34.155.000 \\
\hline \multicolumn{2}{|l|}{ Cost Pool VI } \\
\hline \multicolumn{2}{|l|}{ Aktivitas Penggajian : } \\
\hline Gaji karyawan & 2.139.050.000 \\
\hline Seragam karyawan & 5.254 .000 \\
\hline Jumlah & 2.144 .304 .000 \\
\hline \multicolumn{2}{|l|}{ Cost Pool VII } \\
\hline \multicolumn{2}{|l|}{ Aktivitas penyusutan : } \\
\hline \multicolumn{2}{|l|}{ Penyusutan bangunan dan peralatan } \\
\hline \\
\hline Pemeliharaan & 233.894 .749 \\
\hline Jumlah & 276.482.074 \\
\hline Total Biaya & 3.800.205.554 \\
\hline
\end{tabular}

Sumber : Data hasil olahan, 2018.

Tabel 7. menjelaskan bahwa jumlah biaya Cost Pool I sebesar Rp.357.034.209, jumlah biaya Cost Pool II sebesar Rp.588.210.000 dari hasil perhitungan harga aktivitas pemberian makan pagi dikali 16.806 orang, jumlah biaya Cost Pool III sebesar 
Rp.21.150.000, jumlah biaya Cost Pool IV sebesar Rp.378.870.271, jumlah biaya Cost Pool V sebesar Rp.34.155.000, jumlah biaya Cost Pool VI sebesar Rp.2.144.304.000, jumlah biaya Cost Pool VII sebesar Rp.276.482.074. Total biaya semua activity cost pool sebesar Rp.3.800.205.554.

Tabel 8. Pengalokasian Data Cost Driver

\begin{tabular}{|c|c|c|}
\hline No. & Cost Driver & Jumlah \\
\hline \multirow[t]{6}{*}{1.} & Alokasi jumlah kamar terjual & \\
\hline & Garden View & 1.652 \\
\hline & Pool View & 3.437 \\
\hline & Sea View & 2.796 \\
\hline & Grand Sea View & 518 \\
\hline & Total & 8.403 \\
\hline \multirow[t]{6}{*}{2.} & Alokasi jumlah tamu menginap : & \\
\hline & Garden View & 3.304 \\
\hline & Pool View & 6.874 \\
\hline & Sea View & 5.592 \\
\hline & Grand Sea View & 1.036 \\
\hline & Total & 16.806 \\
\hline \multirow[t]{6}{*}{3.} & Alokasi jumlah kamar tersedia : & \\
\hline & Garden View & 4.380 \\
\hline & Pool View & 7.300 \\
\hline & Sea View & 4.015 \\
\hline & Grand Sea View & 1.460 \\
\hline & Total & $\mathbf{1 7 . 1 5 5}$ \\
\hline \multirow[t]{6}{*}{4.} & Alokasi jumlah pemakaian listrik kWh & \\
\hline & Garden View & $49.062,4$ \\
\hline & Pool View & $109.087,8$ \\
\hline & Sea View & $80.050,46$ \\
\hline & Grand Sea View & 20.012 \\
\hline & Total & $258.212,66$ \\
\hline \multirow[t]{6}{*}{5.} & Alokasi jumlah pemakaian air $\mathrm{m}^{3}$ : & \\
\hline & Garden View & $1.529,6$ \\
\hline & Pool View & $2.505,41$ \\
\hline & Sea View & $2.130,62$ \\
\hline & Grand Sea View & 950 \\
\hline & Total & $7.115,63$ \\
\hline \multirow[t]{6}{*}{6.} & Alokasi jumlah bulan kerja karyawan : & \\
\hline & Garden View (12 karyawan x 12 bulan) & 144 \\
\hline & Pool View (21 karyawan x 12 bulan) & 252 \\
\hline & Sea View (12 karyawan x 12 bulan) & 144 \\
\hline & $\begin{array}{l}\text { Grand Sea View ( } 6 \text { karyawan x } 12 \text { bulan) } \\
\text { ( } 51 \text { karyawan x } 12 \text { bulan) }\end{array}$ & 72 \\
\hline & Total & 612 \\
\hline \multirow[t]{6}{*}{7.} & Alokasi jumlah luas lantai & \\
\hline & Garden View & 294 \\
\hline & Pool View & 720 \\
\hline & Sea View & 528 \\
\hline & Grand Sea View & 264 \\
\hline & Total & 1.806 \\
\hline
\end{tabular}

Sumber: Data hasil olahan, 2018. 
Tabel 8. menunjukkan total pengalokasian data cost driver yang terdiri dari total jumlah kamar terjual 8.403, jumlah tamu menginap 16.806, jumlah kamar tersedia 17.155, jumlah pemakaian listrik $\mathrm{kWh} 258.212,66$, jumlah $\mathrm{m}^{3} 7.115,63$, jumlah bulan kerja karyawan 612, jumlah luas lantai semua kamar $1.806 \mathrm{~m}^{2}$.

\section{Menentukan Tarif Per Unit Cost Driver}

Tabel 9. Tarif Per Unit Cost Driver

\begin{tabular}{|l|c|c|c|}
\hline \multicolumn{1}{|c|}{ Cost Pool } & $\begin{array}{c}\text { Jumlah Biaya (Rp.) } \\
(\mathbf{1})\end{array}$ & $\begin{array}{c}\text { Cost Driver } \\
\mathbf{( 2 )}\end{array}$ & $\begin{array}{c}\text { Tarif per Unit (Rp.) } \\
(\mathbf{1}) \mathbf{: ( 2 )}\end{array}$ \\
\hline Cost Pool I & 357.034 .209 & 8.403 & $42.488,89$ \\
\hline Cost Pool II & 588.210 .000 & 16.806 & 35.000 \\
\hline Cost Pool III & 21.150 .000 & 17.155 & $1.232,88$ \\
\hline Cost Pool IV & 378.870 .271 & $258.212,66$ & $1.467,28$ \\
\hline Cost Pool V & 34.155 .000 & $7.115,63$ & 4.800 \\
\hline Cost Pool VI & 2.144 .304 .000 & 612 & $3.503 .764,71$ \\
\hline Cost Pool VII & 276.482 .074 & 1.806 & $153.090,85$ \\
\hline
\end{tabular}

Sumber: Data hasil olahan, 2018.

Tabel 9. Menunjukkan tarif per unit cost driver yaitu dengan cara perhitungan tiap jumlah biaya cost pool dibagi dengan total cost driver. Dengan hasil sebagai berikut : Cost Pool I Rp.42.488,89, Cost Pool II Rp.35.000, Cost Pool III Rp.1.232,88, Cost Pool IV Rp.1.467,28, Cost Pool V Rp.4.800, Cost Pool VI Rp. 3.503.764,71 dan Cost Pool VII Rp.153.090,85.

5. Membebankan biaya ke produk dengan menggunakan tarif cost driver dan ukuran aktivitas

Tahap ini menurut Hansen dan Mowen (2012:138) biaya aktivitas dibebankan ke produk berdasarkan konsumsi masing-masing aktivitas produk. Pembebanan biaya overhead dari tiap aktivitas ke setiap kamar dihitung dengan rumus sebagai berikut :

BOP yang dibebankan = Tarif per unit Cost Driver X Cost Driver yang digunakan

Mengetahui BOP (biaya overhead pabrik) yang dibebankan pada masing-masing produk, maka dapat dihitung harga jual kamar. Menurut Mulyadi (2013) perhitungan harga jual masing-masing jenis kamar dengan metode $\mathrm{ABC}$ dapat dihitung dengan rumus sebagai berikut :

Harga Jual per Kamar = Harga Pokok per Kamar + Laba yang diharapkan

Untuk harga pokok per kamar diperoleh dari tarif per unit cost driver dibagi dengan cost driver yang digunakan. Sedangkan laba yang diharapkan ditetapkan pihak manajemen PT Tasik Ria Resort yaitu sebesar $40 \%$.

Berikut ini perhitungan harga pokok dan menentukan harga jual untuk masing-masing jenis kamar (Tabel 10 sampai dengan Tabel 13) : 
Tabel 10. Harga Jual Kamar untuk Garden View

\begin{tabular}{|c|c|c|c|c|}
\hline No. & Cost Pool & Tarif Per Unit Cost Driver & Cost Driver & Jumlah (Rp.) \\
\hline 1. & Cost Pool I & $42.488,89$ & 1.652 & $70.191 .646,28$ \\
\hline 2. & Cost Pool II & 35.000 & 3.304 & 115.640 .000 \\
\hline 3. & Cost Pool III & $1.232,88$ & 4.380 & $5.400 .014,4$ \\
\hline 4. & Cost Pool IV & $1.467,28$ & $49.062,4$ & $71.988 .278,27$ \\
\hline 5. & Cost Pool V & 4800 & $1.529,6$ & 7.342 .080 \\
\hline 6. & Cost Pool VI & $3.503 .764,71$ & 144 & $504.542 .117,65$ \\
\hline 7. & Cost Pool VII & $153.090,85$ & 294 & $45.008 .709,9$ \\
\hline \multicolumn{4}{|c|}{ Total biaya untuk tipe Garden View } & $820.112 .846,5$ \\
\hline \multicolumn{4}{|c|}{ Jumlah Kamar Terjual } & 1.652 \\
\hline \multicolumn{4}{|c|}{ Harga Pokok Kamar } & $496.436,35$ \\
\hline \multicolumn{4}{|c|}{$40 \%$ Laba yg diharapkan } & $198.574,54$ \\
\hline \multicolumn{4}{|c|}{ Harga Jual Kamar Garden View } & 695.010,89 \\
\hline
\end{tabular}

Sumber : Data hasil olahan, 2018.

Tabel 10. Dapat dilihat perhitungan harga pokok kamar dan penetuan harga jual kamar jenis Garden View di PT Tasik Ria Resort yaitu harga pokok sebesar Rp.496.436,35 dan harga jual sebesar Rp.695.010,89.

Tabel 11. Harga Jual Kamar untuk Pool View

\begin{tabular}{|c|c|c|c|c|}
\hline No. & Cost Pool & Tarif Per Unit Cost Driver & Cost Driver & Jumlah (Rp.) \\
\hline 1. & Cost Pool I & $42.488,89$ & 3.437 & $146.034 .314,93$ \\
\hline 2. & Cost Pool II & 35.000 & 6.874 & 240.590 .000 \\
\hline 3. & Cost Pool III & $1.232,88$ & 7.300 & 9.000 .024 \\
\hline 4. & Cost Pool IV & $1.467,28$ & 52.416 & $160.062 .347,18$ \\
\hline 5. & Cost Pool V & 4800 & $2.505,41$ & 12.025 .968 \\
\hline 6. & Cost Pool VI & $3.503 .764,71$ & 252 & $882.948 .706,92$ \\
\hline 7. & Cost Pool VII & $153.090,85$ & 720 & 110.225 .412 \\
\hline \multicolumn{4}{|c|}{ Total biaya untuk tipe Pool View } & $1.560 .886 .773,03$ \\
\hline \multicolumn{4}{|c|}{ Jumlah Kamar Terjual } & 3.437 \\
\hline \multicolumn{4}{|c|}{ Harga Pokok Kamar } & $454.142,21$ \\
\hline \multicolumn{4}{|c|}{ 40\% Laba yg diharapkan } & $181.656,88$ \\
\hline \multicolumn{4}{|c|}{ Harga Jual Kamar Pool View } & 635.799,09 \\
\hline
\end{tabular}

Sumber: Data hasil olahan, 2018.

Tabel 11. Dapat dilihat perhitungan harga pokok kamar dan penetuan harga jual kamar jenis Pool View di PT Tasik Ria Resort yaitu harga pokok sebesar Rp.454.142,21 dan harga jual sebesar Rp.635.799,09. 
Tabel 12. Harga Jual Kamar untuk Sea View

\begin{tabular}{|c|c|c|c|c|}
\hline No. & Cost Pool & Tarif Per Unit Cost Driver & Cost Driver & Jumlah (Rp.) \\
\hline 1. & Cost Pool I & $42.488,89$ & 2.796 & $118.798 .936,44$ \\
\hline 2. & Cost Pool II & 35.000 & 5.592 & 195.720 .000 \\
\hline 3. & Cost Pool III & $1.232,88$ & 4.015 & $4.950 .013,2$ \\
\hline 4. & Cost Pool IV & $1.467,28$ & $80.050,46$ & $117.456 .438,95$ \\
\hline 5. & Cost Pool V & 4800 & $2.130,62$ & 10.226 .976 \\
\hline 6. & Cost Pool VI & $3.503 .764,71$ & 144 & $504.542 .117,65$ \\
\hline 7. & Cost Pool VII & $153.090,85$ & 528 & $80.831 .968,8$ \\
\hline \multicolumn{4}{|c|}{ Total biaya untuk tipe Sea View } & $1.032 .526 .451,04$ \\
\hline \multicolumn{4}{|c|}{ Jumlah Kamar Terjual } & 2.796 \\
\hline \multicolumn{4}{|c|}{ Harga Pokok Kamar } & $369.286,99$ \\
\hline \multicolumn{4}{|c|}{$40 \%$ Laba yg diharapkan } & $147.714,79$ \\
\hline \multicolumn{4}{|c|}{ Harga Jual Kamar Sea View } & $517.001,79$ \\
\hline
\end{tabular}

Sumber : Data hasil olahan, 2018.

Tabel 12. Dapat dilihat perhitungan harga pokok kamar dan penetuan harga jual kamar jenis Sea View di PT Tasik Ria Resort yaitu harga pokok sebesar Rp.369.286,99 dan harga jual sebesar Rp.517.001,79.

Tabel 13. Harga Jual Kamar untuk Grand Sea View

\begin{tabular}{|c|c|c|c|c|}
\hline No. & Cost Pool & Tarif Per Unit Cost Driver & Cost Driver & Jumlah (Rp.) \\
\hline 1. & Cost Pool I & $42.488,89$ & 518 & $22.009 .245,02$ \\
\hline 2. & Cost Pool II & 35.000 & 1.036 & 36.260 .000 \\
\hline 3. & Cost Pool III & $1.232,88$ & 1.460 & $1.800 .004,8$ \\
\hline 4. & Cost Pool IV & $1.467,28$ & 20.012 & $29.363 .207,36$ \\
\hline 5. & Cost Pool V & 4800 & 950 & 4.560 .000 \\
\hline 6. & Cost Pool VI & $3.503 .764,71$ & 72 & $252.271 .059,12$ \\
\hline 7. & Cost Pool VII & $153.090,85$ & 264 & $40.415 .984,4$ \\
\hline \multicolumn{4}{|c|}{ Total biaya untuk tipe Grand Sea View } & $386.679 .500,7$ \\
\hline \multicolumn{4}{|c|}{ Jumlah Kamar Terjual } & 518 \\
\hline \multicolumn{4}{|c|}{ Harga Pokok Kamar } & $746.485,52$ \\
\hline \multicolumn{4}{|c|}{ 40\% Laba yg diharapkan } & $298.594,21$ \\
\hline \multicolumn{4}{|c|}{ Harga Jual Kamar Grand Sea View } & 1.045.079,73 \\
\hline
\end{tabular}

Sumber : Data hasil olahan, 2018.

Tabel 13. Dapat dilihat perhitungan harga pokok kamar dan penentuan harga jual kamar jenis Grand Sea View di PT Tasik Ria Resort yaitu harga pokok sebesar Rp.746.485,52 dan harga jual sebesar Rp.1.045.079,73.

Tabel 14. Harga Jual Kamar Hotel Dengan Pajak

\begin{tabular}{|l|c|c|c|}
\hline \multicolumn{1}{|c|}{ Jenis Kamar } & $\begin{array}{c}\text { Harga Jual Kamar } \\
(\mathbf{1})\end{array}$ & Pajak Hotel & $\begin{array}{c}\text { Harga Jual Kamar } \\
\text { Dengan Pajak } \\
\mathbf{( 3 ) = ( 1 ) + ( 2 )}\end{array}$ \\
\hline Garden View & $695.010,89$ & $69.501,09$ & $764.511,98$ \\
\hline Pool View & $635.799,09$ & $63.579,91$ & $699.378,99$ \\
\hline Sea View & $517.001,79$ & $51.700,18$ & $568.701,97$ \\
\hline Grand Sea View & $1.045 .079,73$ & $104.507,97$ & $1.149 .587,7$ \\
\hline
\end{tabular}

Sumber: Data hasil olahan, 2018. 
Tabel 14. Menunjukkan harga jual kamar dengan pajak yaitu dengan cara perhitungan harga jual tiap jenis kamar dikali dengan pajak hotel 10\%. Dengan hasil sebagai berikut : Garden View sebesar Rp.764.511,98, Pool View sebesar Rp.699.378,99, Sea View sebesar Rp.568.701,97 dan Grand Sea View sebesar Rp.1.149.587,7.

\section{Perbandingan Antara Harga Jual Kamar Menggunakan Metode Akuntansi Tradisional dan Harga Jual Kamar Menggunakan Metode Activity Based Costing System}

\section{Tabel 15. Perbandingan Harga Jual Kamar dengan Menggunakan Metode Tradisional} dan Activity Based Costing System

\begin{tabular}{|l|c|c|c|}
\hline \multicolumn{1}{|c|}{ Jenis Kamar } & $\begin{array}{c}\text { Harga Jual Kamar } \\
\text { Perusahaan } \\
\text { (Rp.) }\end{array}$ & $\begin{array}{c}\text { Harga Jual Kamar Sistem } \\
\text { Activity Based Costing } \\
\text { (Rp.) }\end{array}$ & $\begin{array}{c}\text { Selisih } \\
\text { (Rp.) }\end{array}$ \\
\hline Garden View & 584.000 & $764.511,98$ & $(180.511,98)$ \\
\hline Pool View & 797.000 & $699.378,99$ & $97.621,01$ \\
\hline Sea View & 1.089 .000 & $568.701,97$ & $520.298,03$ \\
\hline Grand Sea View & 1.452 .000 & $1.149 .587,7$ & $302.412,3$ \\
\hline
\end{tabular}

Sumber: Data hasil olahan, 2018.

Tabel 15. menunjukkan hasil perhitungan harga jual kamar dengan menggunakan metode ABC untuk jenis kamar Garden View sebesar Rp.764.511,98. Untuk jenis kamar Pool View sebesar Rp.699.378,99. Untuk jenis kamar Sea View sebesar Rp.568.701,97. Untuk kamar Grand Sea View sebesar Rp.1.149.587,7. Dari hasil yang diperoleh dapat dibandingkan selisih harga jual kamar yang telah ditentukan manajemen PT Tasik Ria Resort dengan hasil perhitungan menggunakan metode Activity Based Costing. Untuk metode ABC pada kamar Pool View, Sea View, dan Grand Sea View memberikan hasil perhitungan yang lebih kecil daripada harga jual kamar yang telah ditentukan oleh pihak manajemen hotel. Yaitu dengan selisih harga untuk kamar Pool View sebesar Rp.97.621,01. Untuk kamar Sea View sebesar Rp.520.298,03. Dan untuk kamar Grand Sea View sebesar Rp.302.412,3. Sedangkan pada kamar Garden View hasil perhitungan ABC lebih besar daripada harga jual kamar yang telah ditentukan oleh manajemen hotel. Yaitu dengan selisih sebesar Rp.180.511,98.

\subsection{Pembahasan}

Tarif jasa inap/harga jual kamar pada perusahaan jasa dapat dihitung dengan metode activity based costing (ABC). Dari penelitian yang dilakukan diperoleh suatu penjelasan bahwa PT Tasik Ria Resort Manado belum menerapkan ABC untuk menghitung harga jual kamar. Selama ini PT Tasik Ria Resort masih menggunakan perhitungan harga jual kamar menggunakan sistem tradisional. Terdapat beberapa tahapan dalam menghitung harga pokok untuk menentukan harga jual kamar menggunakan metode $\mathrm{ABC}$ antara lain mengidentifikasi aktivitas, menentukan biaya yang terkait dengan masing-masing aktivitas, mengelompokkan aktivitas yang seragam menjadi satu, menggabungkan biaya dari aktivitas yang dikelompokan, menghitung tarif per kelompok aktivitas dan membebankan biaya aktivitas pada produk. Perhitungan harga jual kamar dilakukan setelah pembebanan biaya aktivitas pada produk dengan cara menambah harga pokok dengan laba yang diharapkan pihak hotel.

Dilihat pada hasil penelitian diatas dapat dilihat perbandingan antara tarif jasa inap/harga jual kamar menggunakan akuntansi tradisional dengan metode ABC. Untuk perhitungan menggunakan ABC system pada jenis kamar Pool View, Sea View dan Grand Sea View memberikan hasil yang lebih rendah dibandingkan dengan harga jual kamar yang ditentukan oleh pihak manajemen PT Tasik Ria Resort yaitu dengan selisih harga untuk kamar jenis Pool View sebesar Rp.97.621,01, untuk kamar jenis Sea View sebesar 
Rp.520.298,03 dan untuk kamar jenis Grand Sea View sebesar Rp.302.412,3. Sedangkan untuk kamar jenis Garden View hasil perhitungan harga jual menggunakan ABC system memberikan hasil yang lebih tinggi dibandingkan dengan harga jual kamar yang ditentukan oleh pihak manajemen PT Tasik Ria Resort yaitu dengan selisih harga sebesar Rp.180.511,98. Perbedaan hasil yang terjadi disebabkan karena perhitungan menggunakan sistem tradisional biaya overhead pada masing-masing produk dibebankan hanya pada satu cost driver saja, sehingga akibatnya terjadi distorsi pada pembebanan biaya overhead dan menghasilkan perhitungan yang tidak relevan. Sedangkan pada metode ABC biaya overhead pada masing-masing produk banyak cost driver yang dibebankan sehingga mampu mengalokasikan biaya ke setiap produk secara tepat berdasarkan masing-masing aktivitas yang dikonsumsi.

\section{KESIMPULAN DAN SARAN}

\subsection{Kesimpulan}

Berdasarkan hasil penelitian dan pembahasan yang dilakukan oleh penulis pada PT

Tasik Ria Resort, maka ditarik kesimpulan sebagai berikut :

1. Perhitungan biaya produk yang telah digunakan oleh manajemen perusahaan telah banyak menimbulkan distorsi biaya, hal ini dikarenakan konsumsi sumber daya pada masing-masing aktivitas tidaklah sama. Sedangkan pada metode ABC, biaya-biaya yang terjadi dibebankan pada produk atas dasar aktivitas dan sumber daya yang dikonsumsi oleh produk dan juga menggunakan dasar lebih dari satu cost driver.

2. Hasil perhitungan harga jual kamar dengan menggunakan metode ABC untuk jenis kamar Garden View sebesar Rp.764.511,98. Untuk jenis kamar Pool View sebesar Rp.699.378,99. Untuk jenis kamar Sea View sebesar Rp.568.701,97. Untuk kamar Grand Sea View sebesar Rp.1.149.587,7. Dari hasil yang diperoleh selisih harga jual kamar dapat dibandingkan dengan yang telah ditentukan manajemen PT Tasik Ria Resort dan hasil perhitungan menggunakan metode ABC. Untuk metode ABC pada kamar Pool View, Sea View, dan Grand Sea View memberikan hasil perhitungan yang lebih kecil daripada harga jual kamar yang telah ditentukan oleh pihak manajemen hotel. Yaitu dengan selisih harga untuk kamar Pool View sebesar Rp.97.621,01. Untuk kamar Sea View sebesar Rp.520.298,03. Dan untuk kamar Grand Sea View sebesar Rp.302.412,3. Sedangkan pada kamar Garden View hasil perhitungan ABC lebih besar daripada harga jual kamar yang telah ditentukan oleh manajemen hotel. Yaitu dengan selisih sebesar Rp.180.511,98.

\subsection{Saran}

Saran yang diberikan penulis adalah melihat persaingan yang begitu ketat di dunia jasa perhotelan maka pihak PT Tasik Ria Resort sebaiknya mulai mempertimbangkan untuk menerapkan $\mathrm{ABC}$ system dalam perhitungan harga pokoknya karena dengan $\mathrm{ABC}$ dapat diperoleh informasi biaya jasa inap yang lebih akurat. Sehingga dalam menentukan harga jual kamar, informasi biaya ini dapat dipertimbangkan dan laba yang sebenarnya diperoleh dari penjualan jasa perhotelan dapat diketahui dengan pasti.

\section{DAFTAR PUSTAKA}

Ahmad, Firdaus. 2014. Akuntansi Biaya. Edisi 3. Salemba Empat. Jakarta.

Ardino. 2017. Analisis Penerapan Metode Activity Based Costing dalam Menentukan Sewa Kamar Penginapan (Studi pada Wakatobi Dive Resort Onemoba'a Tomia). Skripsi. Fakultas Ekonomi dan Bisnis Universitas Halu Oleo. Kendari. 
Darminto, Dwi P. dan Aji Suryo. 2012. Analisis Laporan Keuangan Hotel. Yogyakarta: Andi.

Dunia, Firdaus Ahmad dan Wasilah Abdullah. 2012. Akuntansi Biaya. Edisi Ketiga. BPFE. Yogyakarta.

Rudianto. 2013. Akuntansi Manajemen Informasi untuk Pengambilan Keputusan Strategis. Erlangga. Jakarta.

Siregar, Baldric, Bambang Suripto, Dodi Hapsori. 2014. Akuntansi Biaya. Edisi Kedua. Salemba Empat. Jakarta.

Slamet, Achmad. 2016. Penganggaran Perencanaan \& Pengendalian Usaha. UNNES Press. Semarang.

Sulastinoyo, Agus. 2011. Manajemen Penyelenggaraan Hotel. Alfabeta. Bandung Swastha, Basu. 2013. Manajemen Penjualan. Edisi 3. BPFE. Yogyakarta.

Witjaksono, Armanto. 2013. Akuntansi Biaya. Edisi Revisi. Graha Ilmu. Yogyakarta

Warindrani, Armila Krisna. 2013. Akuntansi Manajemen. Graha Ilmu. Jogjakarta. 